\title{
Pathogenesis of bronchopulmonary dysplasia: when inflammation meets organ development
}

\author{
Tayyab Shahzad ${ }^{1,2}$, Sarah Radajewski ${ }^{1,2}$, Cho-Ming Chao ${ }^{1,2}$, Saverio Bellusci ${ }^{2}$ and Harald Ehrhardt ${ }^{1,2^{*}}$ (D
}

\begin{abstract}
Bronchopulmonary dysplasia is a chronic lung disease of preterm infants. It is caused by the disturbance of physiologic lung development mainly in the saccular stage with lifelong restrictions of pulmonary function and an increased risk of abnormal somatic and psychomotor development. The contributors to this disease's entity are multifactorial with pre- and postnatal origin. Central to the pathogenesis of bronchopulmonary is the induction of a massive pulmonary inflammatory response due to mechanical ventilation and oxygen toxicity. The extent of the pro-inflammatory reaction and the disturbance of further alveolar growth and vasculogenesis vary largely and can be modified by prenatal infections, antenatal steroids, and surfactant application.

This minireview summarizes the important recent research findings on the pulmonary inflammatory reaction obtained in patient cohorts and in experimental models. Unfortunately, recent changes in clinical practice based on these findings had only limited impact on the incidence of bronchopulmonary dysplasia.
\end{abstract}

Keywords: Bronchopulmonary dysplasia, Chronic lung disease of the preterm infant, Lung development, Inflammation, Apoptosis, Alveologenesis, Vasculogenesis, Infection, Antenatal steroids, Surfactant

\section{Introduction}

Bronchopulmonary dysplasia (BPD) is a chronic lung disease of preterm infants. The current worldwide used classification takes into account the need for mechanical ventilation and oxygen supplementation at 28 days of life and at 36 weeks of gestation. Despite major treatment advances during the last two decades, the incidence of BPD is still above $30 \%$ in preterms below 30 weeks of gestation in most European countries [1]. Extremely preterm infants are delivered in the saccular stage of lung development. BPD is caused by the disturbance of lung development in this critical period. The diagnosis is associated with lifelong restrictions of pulmonary function and increases the risk for abnormal somatic and psychomotor development [2]. The inflammatory alterations

\footnotetext{
* Correspondence: Harald.Ehrhardt@paediat.med.uni-giessen.de ${ }^{1} 1$ Department of General Pediatrics and Neonatology, Center for Pediatrics and Youth Medicine, Justus-Liebig-University, Feulgenstrasse 12, D-35392 Gießen, Universities of Gießen and Marburg Lung Center (UGMLC), Member of the German Lung Research Center (DZL), Giessen, Germany

${ }^{2}$ University of Giessen Lung Center, Excellence Cluster Cardio-Pulmonary Systems, Member of the German Lung Center, Department of Internal Medicine II, Aulweg 130, 35392 Giessen, Germany
}

observed in preterms developing BPD are restricted to the neonatal period, but the pulmonary metabolomic abnormalities persist into adulthood. Current animal experiences raise fears that former preterms will develop a COPD-like phenotype later in life with all the consequences for quality of life and life expectancy [3-6]. The factors contributing to this disease's entity can be separated into pre-, peri-, and postnatal causes. Within the ante- and perinatal factors, genetic susceptibility, the immaturity of the surfactant homeostasis, intrauterine and perinatal infections, and lung growth restriction due to placenta insufficiency are central factors impacting on the development of BPD. The postnatal lifesaving therapies of mechanical ventilation and oxygen therapy induce a pulmonary inflammatory response. Lung development is further affected by fluid overload and nutritional deficits (Fig. 1). Despite the progress in the mechanistic understanding of the pathogenesis of BPD, the therapeutic options to prevent this disease are still limited and drug therapies are of low efficiency resulting in an only modest reduction of BPD incidence $[7,8]$. 


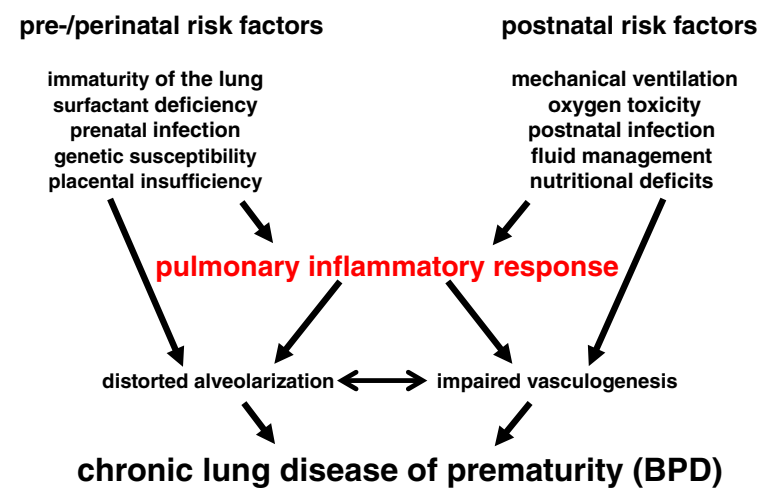

Fig. 1 Central risk factors for BPD development. Depicted are the central pre-/perinatal and postnatal risk factors contributing to the pathogenesis of BPD

We will discuss in detail the recent advances in the understanding of physiologic lung development and the central contribution of the pulmonary inflammatory response to the disturbance of this highly orchestrated process. The potentials and limitations of established and new therapeutic strategies are discussed based on recent preterm cohort studies.

\section{Alterations of normal lung development \\ Stages of lung development}

Physiologic lung development is a highly orchestrated process which in the end enables the gas exchange between the air-conducting parts of the lung and the blood vessels. The stages of lung development can be divided into the embryonic, the pseudoglandular, the canalicular, the saccular, and the alveolar stage. During the embryonic stage, the lung bud separates from the gut followed by the branching morphogenesis in the pseudoglandular stage until 17 weeks of gestation. The pseudoglandular stage is followed by the canalicular stage which continuous until the border of viability at about 24 weeks. The canalicular stage is characterized by the formation of the terminal branches of the bronchial tree, differentiation of type I and type II cells, vascular outgrowth, and the thinning of the mesenchyme. The subsequent saccular stage is mainly characterized by the formation of the primitive terminal airspaces, thinning of the connective tissue between the airspace and the pulmonary vessels, and the beginning of surfactant production. The saccular stage is marked by a dramatic improvement of the prerequisites for gas exchange, and any derangement of this vulnerable period will lead to relevant limitations of gas exchange.

\section{Consequences of disruption of lung development in the saccular stage}

Premature birth in the early phase of the saccular stage leads to disruption of lung development and impaired septation. The pro-inflammatory pulmonary response which is provoked by infection, mechanical ventilation, and oxygen therapy negatively impacts these critical steps which results in a reduced number of alveoli, reduced surface area for gas exchange, and simplified alveolar structures. These impairments have dramatic consequences for gas exchange, and many preterms need prolonged periods of mechanical ventilation, respiratory support, and oxygen delivery. The further lung development during the alveolar stage cannot induce a catch-up growth which leads to relevant limitations of lung function persisting into adulthood $[9,10]$. The impairments of development of the air-conducting parts of the lung are accompanied by a more or less serious distortion of pulmonary vascular development. This double pathology was confirmed in lung tissue sections from patients with severe BPD and leads to the clinical situation of a double limitation of gas exchange due to a restriction of the lung surface area and a reduced capillary network. More severe restrictions of lung function run a higher risk to develop pulmonary hypertension which is of clinical relevance in up to $25 \%$ of preterms with the diagnosis of BPD [11].

\section{Central signaling pathways for alveolar and vascular development}

For the molecular understanding of alveolar and vascular lung development, we have to rely on the data from animal models which clearly demonstrate that alveolar development cannot be uncoupled from vascular development. The proper composition of the extracellular matrix in between is essential for the critical steps of lung developmental, and both alveolar and vascular growth requires the interaction with the extracellular matrix. Vascular endothelial growth factor A (VEGFA) is a key player of vascular development and mediator of NO synthesis in the endothelium. Its inhibition is accompanied by an inhibition of alveologenesis in several animal species [12]. The HIF signaling pathway is a further central regulatory pathway of vascular development, and its dysregulation leads to the distortion of vascular development dependent and independent of VEGFA $[13,14]$. Cytokines of the inflammatory response like MCP-1 or MIP- $1 \alpha$ are able to derange the formation of alveolar capillaries [15]. The parallel development of alveolar and microvascular structures is highly orchestrated by the extracellular matrix which forms the interlayer in between. The development of the secondary septae depends on the proper assembly of elastin fibers at specific sites which is deranged in the pathologic situation. In line with this, elastin haploinsufficiency leads to the distortion of the mesenchyme and of vascular development [16]. In the pathologic situation of lung injury, these fibers are excessively and diffusely deposited in the mesenchyme. Mechanical ventilation leads to 
inappropriate deposition and elastin breakdown accompanied by distortion of further septation [17-19]. Proper elastin fiber deposition is orchestrated by the fibroblasts in the interstitial mesenchyme, and different genetic knockout models have proven that the loss of fibroblasts is associated with severe derangement of normal lung development and remodeling of the extracellular matrix. In animal models mimicking the clinical situation of mechanical ventilation and oxygen therapy in the saccular stage of lung development, the fibroblasts and elastic fibers are diffusely scattered in the mesenchyme and are no longer located at the top of the secondary crests where they normally contribute to further lung growth $[20,21]$. The inhibition of the C-terminal Src kinase (Csk) and the subsequent overweight of epidermal growth factor receptor signaling seem to be critical for the abnormal distribution of lung fibroblasts [22]. Within the further pathways which are critical for normal lung development, two vitamin-dependent signaling pathways have raised special attention: While the retinoic acid pathway is a well-known key regulator of critical steps of lung development, latest data hint that vitamin $\mathrm{D}$ is another positive regulator in the pathologic situation of lung damage [23-25].

\section{The pulmonary inflammatory response}

\section{Imbalance of pro-inflammatory cytokines and growth factors}

Since the early 1990s, it is well known that the pulmonary inflammatory response due to mechanical ventilation and oxygen therapy is characterized by a disbalance of pro-inflammatory cytokines and growth factors followed by the influx of inflammatory cells into the lung. Since the first observations of cytologic changes in the tracheal aspirates of preterms developing BPD, a plenty of studies has detected an association between higher levels of typical pro-inflammatory cytokines like IL-1 $\beta$, IL-6, IL-8, TNF- $\alpha$, monocyte chemo-attractant proteins, and macrophage inflammatory proteins in the tracheal aspirate of the mechanically ventilated preterm infant and the later development of BPD [26, 27]. The initiation of the inflammatory response can already occur in utero, i.e., in the situation of chorioamnionitis [28]. Further evaluation of these markers of inflammation in the tracheal aspirate and peripheral blood of the preterm infant is necessary to confirm the applicability as early biomarkers of disease severity $[29,30]$. The rise in pro-inflammatory cytokines is accompanied by the upregulation of cell adhesion molecules like ICAM-1 and L-selectin and by the increase in chemotactic proteins that attract the inflammatory cells into the lung. The pulmonary attraction of these cells leads to the persistence of the inflammatory response and the accumulation of NF-kB within this cellular fraction. In parallel, the levels of classical antiinflammatory cytokines like IL-10 and of central growth factors of alveolar and vascular growth like VEGFA and PDGFA and the crucial members of the FGF family are decreased in tracheal aspirates and preterm lung tissue sections [31-33]. A certain specificity of the inflammatory reaction can be attributed to the fact that the cytokine levels of not all classical candidates are significantly regulated including IL-4 and IL-13. Of special interest is the focus on cytokines and proteins which regulate normal lung development and participate in tissue remodeling. TGF- $\beta$ and the BMP signaling pathways take a central position with respect to both processes. The activity of TGF- $\beta$ is significantly increased in the tracheal aspirates of preterm infants which later develop severe $\mathrm{BPD}$, and the appearance of $\alpha$-SMA and TGF- $\beta$ positive fibroblasts is increased in the alveolar septae of preterms with BPD [34, 35]. The expression level of matricellular protein SPARC is significantly elevated in tracheal aspirates and lung tissue sections from preterms with severe BPD which regulates cell-matrix interaction and participates in tissue remodeling among other regulatory steps by impacting on TGF- $\beta, \beta$-catenin and VEGFA signaling $[36,37]$. Downstream of TGF- $\beta$, tissue transglutaminase2 and lysyl hydroxylase plod2 were identified as critical regulators of extracellular matrix remodeling [38, 39].

\section{Influx of inflammatory cells into the lung}

The cellular fraction in the tracheal aspirates is dominated by alveolar macrophages which contribute to the persistence of the inflammation by the production of further pro-inflammatory cytokines and by neutrophils which secrete a plenty of proteases, leading to pulmonary tissue damage, cellular apoptosis, and surfactant inactivation. Recent observations suggest that the immaturity of the macrophage phenotype may account not only for the severity of postnatal respiratory distress but also for the progression to BPD [40]. There seems to be a preexisting disbalance between proteinases and proteinase inhibitors in the developing lung which makes it more susceptible to organ damage. The ex utero higher oxygen pressures and the clinical need for increases in oxygen fraction induce further cell damage by the production of reactive oxygen species which cause lung damage by direct lipid peroxidation and aggravate the tissue damage by proteases. The increase of matrix metalloproteinases, cysteine proteases, elastase, and trypsin in the tracheal aspirates of preterms developing BPD suggests an important role in the pathogenesis. Data from clinical studies prove the association between the extent of the pulmonary inflammation and the increase in elastase activity in the tracheal aspirates of preterm infants later developing severe BPD. The elastin breakdown products like desmosine can be detected in higher levels in the urine of preterms 
developing severe BPD and may serve as early markers of disease progression [41, 42].

Recent publications suggest that further cellular fractions like mast cells accumulate in the lung tissue and that reactive $\mathrm{T}$ cells in the peripheral blood also impact on the development of BPD. Their precise role remains to be determined. The phenomenon of immune tolerance or immunoparalysis due to antenatal infection has to be taken into account when evaluating the impact of hematopoietic inflammatory cells on distortion of lung development $[43,44]$. The complexity of the interaction of the immune system with the microbial pathogens probably accounts for the contradictory results of the effects of pathogen colonization and infection on the development of BPD [44-46]. Experimental evidence underlines the importance of the order of exposures which determines the impact on lung inflammation [47]. The lifesaving therapies of mechanical ventilation and oxygen application have a direct impact on the different cell fractions of the lung. For example, the structure and function of airway smooth muscle cells is impacted by hyperoxia in a dose-dependent manner [48]. Besides the pro-inflammatory hematopoietic cells, mesenchymal stromal cells can be detected within the tracheal aspirates. The current scientific findings suggest a negative impact of these cells on the incidence of BPD as they are mainly isolated from tracheal aspirates of preterms with severe BPD and show higher $\beta$-catenin activation $[37,49]$. Caution has to be taken before final conclusions are drawn as in other lung disease entities their precise function is still of controversial debate. The critical steps of inflammation are summarized in Fig. 2.

\section{The complexity of signal transduction}

Animal models were able to reproduce the negative impact of pro-inflammatory cytokines like IL-1 $\beta$ on lung development in the saccular stage and to attribute the activation of the NF-kB signaling a central role in the pathogenesis of BPD. This is further fundamented by experimental data that demonstrate a beneficial effect of attenuation of NF-kB activation on lung development. However, the therapeutic potential of NF-kB inhibition is limited by its essential role in physiologic lung development, mediating both alveologenesis and vasculogenesis. Furthermore, a disease-limiting function of NF-kB in inflammation was attributed to the suppression of macrophage inflammatory protein 2 [50-53]. The physiologic functions of NF-kB in the developing lung are even more complex as it is ubiquitously expressed; controls diverse cellular functions including apoptosis, survival, proliferation, and immune regulation; and exerts simultaneously pro- and anti-inflammatory actions. In line with this, recent data ascribe TNF- $\alpha$, a classical activator of NF-kB signaling, an important role for the limitation of overwhelming TGF- $\beta$ signaling, for the protection from ventilator-induced lung injury and the preservation of lung development [54]. These caveats are further strengthened by the inconsistent results of glucocorticoid actions on the developing lung which are applied to suppress the inflammatory response. Despite their potent anti-inflammatory activity, contradictory effects of glucocorticoids were observed during saccular lung development. On the one hand, they promoted the expansion of distal airways and thinning of the mesenchyme but on the other hand impaired secondary

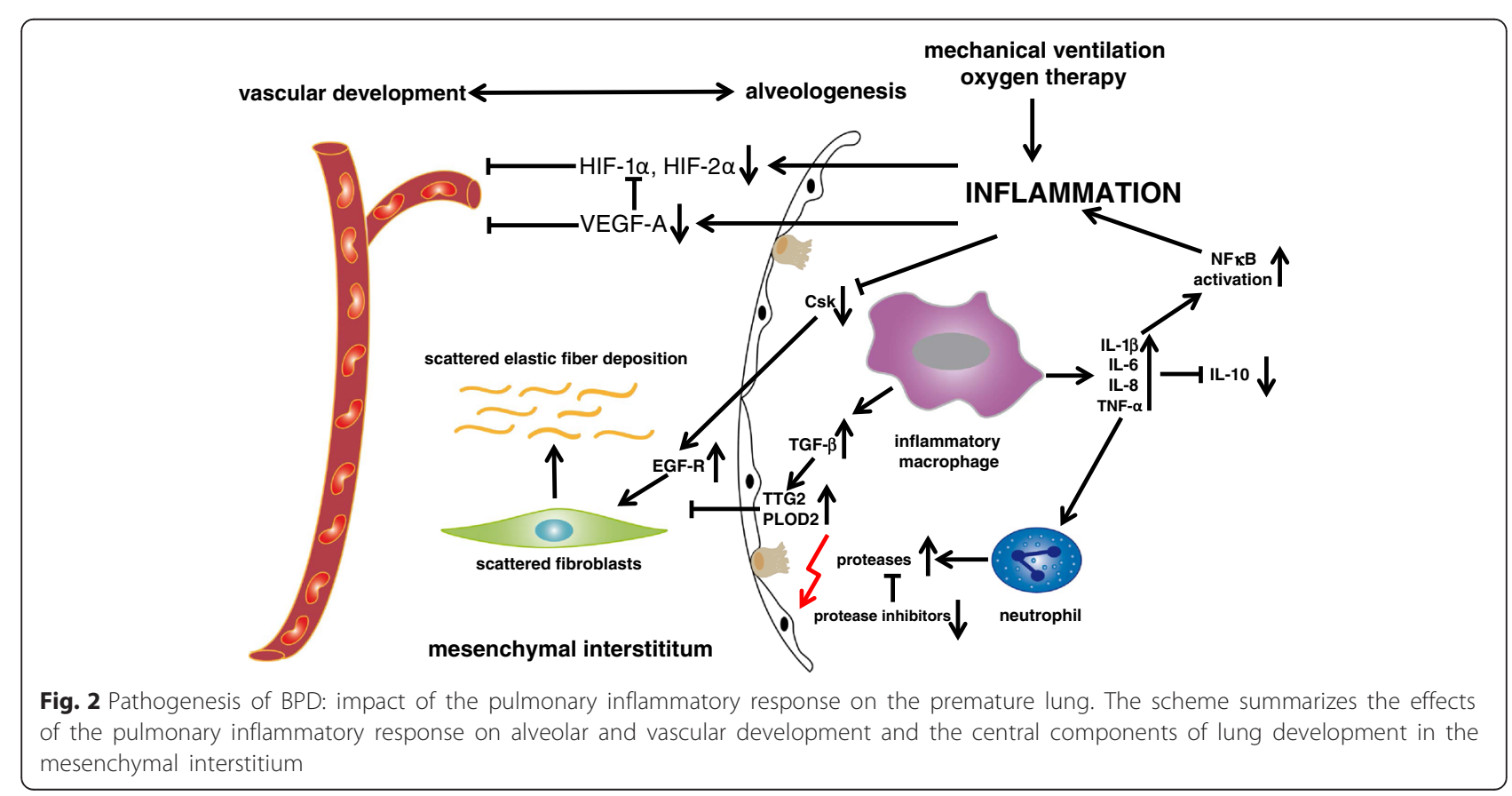


septation [55]. Also for other key regulators like MMP9, the data sets are not consistent and the impact has to be studied within the complexity of the disease $[56,57]$. The appropriate level of TGF- $\beta$ signaling is another example, and the reduction or the abundance of activation of TGF- $\beta$ pathways is associated with distortion of lung development in any stage $[58,59]$. Further complexity arises from differences in clinical practice and, i.e., the course of oxygen support. Recent experimental data hint that not only the duration and fraction of oxygen supply but also the change in oxygen fraction account for differences in disturbance of lung development $[60,61]$.

\section{Improvements in clinical care}

\section{Moderate reduction of BPD incidence by modification of} ventilation strategies

During the recent years, several clinical approaches have been tested to reduce the incidence of BPD. Several randomized controlled multicenter studies have tested the impact of different ventilation strategies to reduce the incidence of BPD: The comparison of initial stabilization of the preterm infant after delivery with CPAP versus intubation and surfactant application did not show inferiority of the CPAP without surfactant application strategy, but it did not significantly impact on the incidence of BPD $[62,63]$. However, the follow-up at the age of 2 years did demonstrate superiority of the CPAP approach with respect to the number of infants with wheeze episodes, respiratory illnesses, and emergency visits [64]. In line with this, the comparison of high-frequency oscillation (HFO) versus conventional ventilation did show superiority of HFO and better lung function at the age of 11-14 years although again the BPD incidence at 36 weeks was not significantly different [65]. These studies underline that long-term follow-up is essential to precisely assess the impact on lung development. Whether the use of a more gentle ventilation strategy tolerating higher $\mathrm{pCO}_{2}$ levels impacts on the long-term pulmonary outcome is still not clear. The short-term pulmonary outcome at 36 weeks of gestation did not lead to a significant reduction in BPD [66]. Besides modification of the ventilation regime, the allocation to different oxygen saturation targets was extensively studied during the recent years. The meta-analysis of the recent multicenter trials with overall more than 5000 infants did not detect a significant difference for the outcome parameter BPD between oxygen saturation limits of $85-89 \%$ versus $90-95 \%$. Here again, long-term followup is urgently needed. The detailed view on all relevant outcome parameters of prematurity revealed that the higher survival rates in the higher $\mathrm{Sp}_{2}$ target group were accompanied by a lower incidence of necrotizing enterocolitis [67]. Therefore, it is essential to take into account all severe complications of preterm birth when comparing different ventilation strategies.

\section{Lack of new drug therapies to prevent BPD}

More than 40 different therapeutic approaches have been tested in randomized controlled trials during the last two decades, but only 4 medications have proven therapeutic efficiency in meta-analyses. Also natural surfactant constitutes a backbone of therapy of respiratory distress of the preterm infant; its impact on the pulmonary outcome gets only visible in the meta-analysis when the parameter BPD is combined with death before discharge [68]. The two initial randomized controlled trials comparing the avoidance of mechanical ventilation by less invasive surfactant application under spontaneous breathing with clinical routine surfactant application via the endotracheal tube were probably underpowered to detect a significant difference with respect to the outcome parameter BPD $[69,70]$. The actual retrospective analysis of a bigger cohort revealed that the sophisticated technique of less invasive surfactant application under spontaneous breathing led to a significant reduction in BPD incidence and overall morbidity [71]. Besides surfactant therapy, both the therapy with caffeine and the intramuscular application of vitamin A significantly reduce the incidence of $\mathrm{BPD}$; also, the mechanisms leading to this reduction are not completely determined in the preterm infant. Despite the therapeutic efficiency to reduce the incidence of BPD the routine use of corticosteroids should be avoided because of the potential side effects on the psychomotor outcome and the potential risks for lung development [55]. Taking into account that efficient new therapeutic drugs to reduce the incidence of BPD are not within reach, the critical evaluation of these well-established drugs might lead to a reduction of BPD in the short term. On the other hand, a plenty of therapeutic strategies that have proven efficient in animal studies displayed no superiority in randomized controlled trials in the preterm infant. One of the major disappointments is the application of inhaled nitric oxide (iNO) during the initial phase of mechanical ventilation. Although iNO proved highly efficient in several animal studies and reduced the pulmonary inflammation, stabilized the surfactant homeostasis, and promoted lung growth, the results of the combined analysis of published randomized trials do not allow a recommendation of the use of iNO in the clinical setting [72].

\section{Conclusion}

The latest data confirm that BPD is not only a multifactorial but a highly complex disease. The precise evaluation of signal transduction and pathway interactions will contribute to a thorough understanding of disease pathology. Investigations of both pathway activation and blockade of signal transduction are necessary for the determination of pathway-specific effects, and the readouts 
should focus on all pathways relevant for normal lung development and lung injury to get a comprehensive view on $\mathrm{BPD}$. This research direction will hopefully overcome the current gap between progress in the molecular understanding of the pathologic alterations in animal models and the only limited advances to reduce the incidence of chronic lung disease in the preterm infant. Future studies are needed which comprehensively study the pathologic processes induced by premature birth, infections, mechanical ventilation, and oxygen therapy. As patient lung tissue samples are not readily available due to the high survival rates of preterm infants and the special disease severity of preterms not surviving till discharge, the search for readily available biomarkers to predict disease severity and to control therapy efficiency in animal and human trials is urgently needed. Furthermore, more specific and precise approaches are necessary to discriminate the different pathologies of BPD which take into account the different causes like antenatal growth restriction, genetic disposition, genderspecific effects, pre- and postnatal infection, and the therapeutic necessities of mechanical ventilation and oxygen toxicity. When considering these variables, a better patient-oriented therapeutic approach is possible which can improve therapeutic efficiency based on the molecular understanding of the different disease pathologies of bronchopulmonary dysplasia. The current need for long-term follow-up can be hopefully avoided by the introduction of more precise parameters to estimate disease severity beyond the dependence on mechanical ventilation and oxygen supplementation at 36 weeks of gestation.

\begin{abstract}
Abbreviations
$\mathrm{BPD}$, bronchopulmonary dysplasia; COPD, chronic obstructive pulmonary disease; CPAP, continuous positive airway pressure; Csk, C-terminal Src kinase; FGF, fibroblast growth factor; HFO, high-frequency oscillation; ICAM-1, intercellular adhesion molecule-1; IL, interleukin; iNO, inhaled nitric oxide; MCP-1, monocyte chemotactic protein 1; MIP-1 a, macrophage inflammatory proteins; MMP-9, matrix metallopeptidase 9; NF-kB, nucleic factor-kB; NO, nitric oxide; $\mathrm{PCO}$, partial pressure of carbon dioxide; PDGFA, platelet-derived growth factor subunit A; SPARC, secreted protein acidic and rich in cysteine; $\mathrm{SpO} 2$, peripheral capillary oxygen saturation; TGF- $\beta$, transforming growth factor $\beta$; VEGFA, vascular endothelial growth factor $A$; $a-S M A$, $a$-smooth muscle actin
\end{abstract}

\section{Competing interests}

The authors declare that they have no competing interests.

\section{Authors' contributions}

HE drafted the manuscript. TS, SR, CMC, and SB commented on the manuscript. All authors read and approved the final version of the manuscript.

\section{Acknowledgements}

Due to space restrictions and the focus of this minireview, we were not able to include all relevant articles to this extensively studied topic. This work was supported by UKGM Forschungsförderung, von Behring Röntgen Stiftung, and COST BM1201.
Received: 15 February 2016 Accepted: 20 June 2016

Published online: 29 June 2016

\section{References}

1. Gortner L, Misselwitz B (2011) Rates of bronchopulmonary dysplasia in very preterm neonates in Europe: results from the MOSAIC cohort. Neonatology 99:112-117. doi:10.1159/000313024

2. Islam JA, Keller RL, Aschner JL, Hartert TV, Moore PE et al (2015) Understanding the Short- and Long-Term Respiratory Outcomes of Prematurity and Bronchopulmonary Dysplasia. Am J Respir Crit Care Med 192(2):134-156. doi:10.1164/rccm.201412-2142PP

3. Didon L, Roos AB, Elmberger GP, Gonzalez FJ, Nord M et al (2010) Lung-specific inactivation of CCAAT/enhancer binding protein a causes a pathological pattern characteristic of COPD. Eur Respir J 35(1):186-197. doi:10.1183/09031936. 00185008

4. Carraro S, Giordano G, Pirillo P, Maretti M, Reniero F, Cogo PE, Perilongo G, Stocchero M, Baraldi E et al (2015) Airway metabolic anomalies in adolescents with bronchopulmonary dysplasia: new insights from the metabolomic approach. J Pediatr 166(2):234-239. doi:10.1016/j.jpeds.2014.08.049

5. Suursalmi P, Kopeli T, Korhonen P, Lehtimäki L, Nieminen R, Luukkaala T, Moilanen E, Korppi M, Paassilta M, Tammela O et al (2015) Very low birthweight bronchopulmonary dysplasia survivors show no substantial association between lung function and current inflammatory markers. Acta Paediatr 104(3):264-268. doi:10.1111/apa.12837

6. Korhonen PH, Suursalmi P, Kopeli T, Nieminen R, Lehtimäki L, Luukkaala T, Korppi M, Saari A, Moilanen E, Tammela OK et al (2015) Inflammatory activity at school age in very low birth weight bronchopulmonary dysplasia survivors. Pediatr Pulmonol 50(7):683-690. doi:10.1002/ppul.23038

7. McEvoy CT, Jain L, Schmidt B, Abman S, Bancalari E, Aschner JL et al (2014) Bronchopulmonary dysplasia: NHLBI Workshop on the Primary Prevention of Chronic Lung Diseases. Ann Am Thorc Soc 11(Suppl 3):S146-S153. doi:10.1513/AnnalsATS.201312-424LD

8. Beam KS, Aliaga S, Ahlfeld SK, Cohen-Wolkowiez M, Smith PB, Laughon MM et al (2014) A systematic review of randomized controlled trials for the prevention of bronchopulmonary dysplasia in infants. J Perinatol 34:705-710. doi:10.1038/jp.2014.126

9. Mullassery D, Smith NP (2015) Lung development. Semin Pedaitr Surg 24(4):152-155. doi:10.1053/j.sempedsurg.2015.01.011

10. Carraro S, Filippone M, Da Dalt L, Ferraro V, Maretti M, Bressan S, El Mazloum D, Baraldi E et al (2013) Bronchopulmonary dysplasia: the earliest and perhaps the longest lasting obstructive lung disease in humans. Early Hum Dev 2013(89 Suppl 3):S3-S5. doi:10.1016/j.earlhumdev.2013.07.015

11. Rossor T, Greenough A (2015) Advances in paediatric pulmonary vascular disease associated with bronchopulmonary dysplasia. Exp Rev Respir Med 9(1):35-43. doi:10.1586/17476348.2015.986470

12. Baker CD, Abman SH (2015) Impaired pulmonary vascular development in bronchopulmonary dysplasia. Neonatology 107(4):344-351. doi:10.1159/000381129

13. Grover TR, Asikainen TM, Kinsella JP, Abman SH, White CW et al (2007) Hypoxia-inducible factors hif-1alpha and hif-2alpha are decreased in an experimental model of severe respiratory distress syndrome in preterm lambs. Am J Physiol Lung Cell Mol Physiol 292(6):L1345-L1351. doi:10.1152/ajplung.00372.2006

14. Miller JD, Benjamin JT, Kelly DR, Frank DB, Prince LS et al (2010) Chorioamnionitis stimulates angiogenesis in saccular stage fetal lungs via CC chemokines. Am J Physiol Lung Cell Mol Physiol 298(5):L637-L645. doi:10.1152/ajplung.00414.2009

15. Compernolle V, Brusselmans K, Acker T, Hoet P, Tjwa M, Beck H, Plaisance $S$, Dor Y, Keshet E, Lupu F, Nemery B, Dewerchin M, Van Veldhoven P, Plate K, Moons L, Collen D, Carmeliet P et al (2002) Loss of HIF-2alpha and inhibition of VEGF impair fetal lung maturation, whereas treatment with VEGF prevents fatal respiratory distress in premature mice. Nat Med 8(7):702-710. doi:10.1038/nm721

16. Hilgendorff A, Parai K, Ertsey R, Navarro E, Jain N, Carandang F, Peterson J, Mokres L, Milla C, Preuss S, Alcazar MA, Khan S, Masumi J, Ferreira-Tojais N, Mujahid S, Starcher B, Rabinovitch M, Bland R et al (2015) Lung matrix and vascular remodeling in mechanically ventilated elastin haploinsufficient newborn mice. Am J Physiol Lung Cell Mol Physiol 308:L464-L478. doi:10.1152/ajplung.00278.2014

17. Husain AN, Siddiqui NH, Stocker JT et al (1998) Pathology of arrested acinar development in postsurfactant bronchopulmonary dysplasia. Hum Pathol 29(7):710-717. doi:10.1016/50046-8177(98)90280-5 
18. Thibeault DW, Mabry SM, Ekekezie II, Truog WE et al (2000) Lung elastic tissue maturation and perturbations during the evolution of chronic lung disease. Pediatrics 106(6):1452-1459. doi:10.1542/peds.106.6.1452

19. Bland RD, Ertsey R, Mokres LM, Xu L, Jacobson BE, Jiang S, Alvira CM, Rabinovitch M, Shinwell ES, Dixit A et al (2008) Mechanical ventilation uncouples synthesis and assembly of elastin and increases apoptosis in lungs of newborn mice: prelude to defective alveolar septation during lung development? Am J Physiol Lung Cell Mol Physiol 294(1):L3-L14. doi:10.1152/ajplung.00362.2007

20. Boström $H$, Willetts $K$, Pekny $M$, Levéen $P$, Lindahl $P$, Hedstrand $H$, Pekna M, Hellström M, Gebre-Medhin S, Schalling M, Nilsson M, Kurland S, Törnell J, Heath JK, Betsholtz C et al (1996) PDGF-A signaling is a critical event in lung alveolar myofibroblast development and alveogenesis. Cell 85(6):863-873, http://dx.doi.org/10.1016/500928674(00)81270-2

21. Mokres LM, Parai K, Hilgendorff A, Ertsey R, Alvira CM, Rabinovitch M, Bland RD et al (2010) Prolonged mechanical ventilation with air induces apoptosis and causes failure of alveolar septation and angiogenesis in lungs of newborn mice. Am J Physiol Lung Cell Mol Physiol 298(1):L23L35. doi:10.1152/ajplung.00251.2009

22. Li J, Li Y, He H, Liu C, Li W, Xie L, Zhang Y et al (2016) Csk/Src/EGFR signaling regulates migration of myofibroblasts and alveolarization. Am Physiol Lung Cell Mol Physiol. doi:10.1152/s00162.2015

23. Malpel S, Mendelsohn C, Cardoso WW et al (2000) Regulation of retinoic acid signaling during lung morphogenesis. Development 127:3057-3067

24. Hind M, Corcoran J, Maden M et al (2002) Pre- and Postnatal Lung Development, Maturation, and Plasticity Temporal/spatial expression of retinoid binding proteins and RAR isoforms in the postnatal lung. Am J Physiol Lung Cell Mol Physiol 282:L468-L476. doi:10.1152/ajplung.00196. 2001

25. Mandell E, Seedorf G, Gien J, Abman SH et al (2014) Vitamin D treatment improves survival and infant lung structure after intra-amniotic endotoxin exposure in rats: potential role for the prevention of bronchopulmonary dysplasia. Am J Physiol Lung Cell Mol Physiol 306:L420-L428. doi:10.1152/ ajplung.00344.2013

26. Todd DA, Earl M, Lloyd J, Greenberg M, John E et al (1998) Cytological changes in endotracheal aspirates associated with chronic lung disease. Early Hum Dev 51(1):13-22. doi:10.1016/S0378-3782(97)00069-8

27. Speer CP (2006) Pulmonary inflammation and bronchopulmonary dysplasia. J Perinatol 26(Suppl1):S57-S62. doi:10.1038/sj.jp.7211476

28. Yoon BH, Romero R, Jun JK, Park KH, Park JD, Ghezzi F, Kim Bl et al (1997) Amniotic fluid cytokines(interleukin-6,tumornecrosisfactor-al pha,interleukin1 beta,and interleukin-8)and the risk for the development of bronchopulmonary dysplasia. Am J Obstet Gynecol 177:825-830, http://dx.doi.org/10.1016/50002-9378(97)70276-X

29. Zhang ZQ, Huang XM, Lu H et al (2014) Early biomarkers as predictors for bronchopulmonary dysplasia in preterm infants: a systematic review. Eur J Pediatr 173(1):15-23. doi:10.1007/s00431-013-2148-7

30. Bhandari V (2014) Postnatal inflammation in the pathogenesis of bronchopulmonary dysplasia. Birth Defects Res A Clin Mol Teratol 100(3):189-201. doi:10.1002/bdra.23220

31. Popova A, Bentley JK, Cui TX, Richardson MN, Lei J, Chen Q et al (2014) Reduced platelet-derived growth factor receptor expression is a primary feature of human bronchopulmonary dysplasia. Am J Physiol Lung Cell Mol Physiol 307(3):L231-L239. doi:10.1152/ajplung.00342.2013

32. Bhatt AJ, Pryhuber GS, Huyck H, Watkins RH, Metlay LA, Maniscalo WM et al (2001) Disrupted Pulmonary Vasculature and Decreased Vascular Endothelial Growth Factor, Flt-1, and TIE-2 in Human Infants Dying with Bronchopulmonary Dysplasia. Am J Respir Crit Care Med 164(10):1971-1980. doi:10.1164/ajrccm.164.10.2101140

33. Speer CP (2006) Inflammation and bronchopulmonary dysplasia: a continuing story. Semin Fetal Neonatal Med 11(5):354-362. doi:10.1016/j. siny.2006.03.004

34. Toti P, Buonocore G, Tanganelli P, Catella AM, Palmeri ML, Vatti R et al (1997) Bronchopulmonary dysplasia of the premature baby: an immunohistochemical study. Pediatr Pulmonol 24:22-28. doi:10.1002/ (SICI) 1099-0496(199707)24:1<22::AID-PPUL4>3.0.CO;2-L

35. Jonsson B, Li YH, Noack G, Brauner A, Tullus K et al (2000) Downregulatory cytokines in tracheobronchial aspirate fluid from infants with chronic lung disease of prematurity. Acta Paediatr 89:1375-1380. doi:10.1111/j.1651-2227. 2000.tb00768.x
36. Popova A, Cui TX, Kaciroti N, Goldsmith AM, Linn MJ, Pryhuber GS, Hershenson MB et al (2015) Tracheal aspirate levels of the matricellular protein SPARC predict development of bronchopulmonary dysplasia. PLoS One. doi:10.1371/s0144122

37. Popova AP, Bentley JK, Anyanwu AC et al (2012) Glycogen synthase kinase-3 $3 / \beta$-catenin signaling regulates neonatal lung mesenchymal stromal cell myofibroblastic differentiation. Am J Physiol Lung Cell Mol Physiol 303(5):L439-L448. doi:10.1152/ajplung.00408.2011

38. Witsch TJ, Niess G, Sakkas E, Likhoshvay T, Becker S, Herold S, Mayer K, Vadász I, Roberts JD Jr, Seeger W, Morty RE et al (2014)

Transglutaminase 2: a new player in bronchopulmonary dysplasia? Eur Respir J 44:109-121. doi:10.1183/09031936.00075713

39. Witsch TJ, Turowski P, Sakkas E, Niess G, Becker S, Herold S, Mayer K, Vadász I, Roberts JD Jr, Seeger W, Morty RE et al (2014) Deregulation of the lysyl hydroxylase matrix cross-linking system in experimental and clinical bronchopulmonary dysplasia. Am J Physiol Lung Cell Mol Physiol 306(3):L246-L259. doi:10.1152/ajplung.00109.2013

40. Prince LR, Maxwell NC, Gill SK, Dockrell DH, Sabroe I, McGreal EP, Kotecha S, Whyte MK et al (2014) Macrophage phenotype is associated with disease severity in preterm infants with chronic lung disease. Plos One 12;9(8):e103059. doi:10.1371/journal.pone.0103059.eCollection2014

41. Ogden BE, Murphy SA, Saunders GC, Pathak D, Johnson JD et al (1984) Neonatal lung neutrophils and elastase/proteinase inhibitor imbalance. Am Rev Respir Dis 130(5):817-821. doi:10.1164/arrd.1984.130.5.817

42. Bruce MC, Wedig KE, Jentoft N, Martin RJ, Cheng PW, Boat TF, Fanaroff AA et al (1985) Altered urinary excretion of elastin cross-links in premature infants who develop bronchopulmonary dysplasia. Am Rev Respir Dis 131(4):568-572. doi:10.1164/arrd.1985.131.4.568

43. Azizia M, Lloyd J, Allen M, Klein N, Peebles D et al (2012) Immune status in very preterm neonates. Pediatrics 129(4):e967-e974. doi:10.1542/peds. 2011-1579d

44. Kallpur SG, Kramer BW, Knox CL, Berry CA, Collins JJ, Kemp MW, Nitsos I, Polglase GR, Robinson J, Hillman NH, Newnham JP, Chougnet C, Jobe AH et al (2011) Chronic fetal exposure to Ureaplasma parvum suppresses innate immune responses in sheep. Immunol 187(5):2688-2695. doi:10.4049/ jimmunol.1100779

45. Lowe J, Watkins WJ, Edwards MO, Spiller OB, Jacqz-Aigrain E, Kotecha SJ, Kotecha $S$ et al (2014) Association between pulmonary ureaplasma colonization and bronchopulmonary dysplasia in preterm infants: updated systematic review and meta-analysis. Pediatr Infect Dis J 33:697-702. doi:10.1097/INF.0000000000000239

46. Hartling L, Liang Y, Lacaze-Masmonteil T et al (2012) Chorioamnionitis as a risk factor for bronchopulmonary dysplasia: a systematic review and meta-analysis. Arch Dis Child Fetal Neonat Ed 97(1):F8-F17. doi:10.1136/ adc.2010.210187

47. Kuypers E, Collins JJ, Kramer BW, Ofman G, Nitsos I, Pillow JJ, Polglase GR, Kemp MW, Newnham JP, Gavilanes AW, Nowacki R, Ikegami M, Jobe AH, Kallapur SG et al (2012) Intra-amniotic LPS and antenatal betamethasone: inflammation and maturation in preterm lamb lungs. Am J Physiol Lung Cell Mol Physiol 302(4):L380-L389. doi:10.1152/ajplung.00338.2011

48. Hartmann WR, Smelter DF, Sathish V, Karass M, Kim S, Aravamudan B, Thompson MA, Amrani Y, Pandya HC, Martin RJ, Prakash YS, Pabelick CM et al (2012) Oxygen dose responsiveness of human fetal airway smooth muscle cells. Am J Physiol Lung Cell Mol Physiol 303(8):L711-L719. doi:10.1152/ajplung.00037.2012

49. Hennrick KT, Keeton AG, Nanua S, Kijek TG, Goldsmith AM, Sajjan US, Bentley JK, Lama VN, Moore BB, Schumacher RE, Thannickal VJ, Hershenson MB et al (2007) Lung Cells from Neonates Show a Mesenchymal Stem Cell Phenotype. Am J Respir Crit Care Med 175(11):1158-1164. doi:10.1164/rccm. 200607-9410C

50. Blackwell TS, Hipps AN, Yamamoto Y, Han W, Barham WJ, Ostrowski MC, Yull FE, Prince LS et al (2011) NF-kappaB signaling in fetal lung macrophages disrupts airway morphogenesis. J Immunol 187:2740-274. doi:10.4049/jimmunol.1101495

51. Iosef C, Alastalo TP, Hou Y, Chen C, Adams ES, Lyu SC, Cornfield DN, Alvira CM et al (2012) Inhibiting NF-kappaB in the developing lung disrupts angiogenesis and alveolarization. Am J Physiol Lung Cell Mol Physiol 302:L1023-L1036. doi:10.1152/ajplung.00230.2011

52. Hou Y, Liu M, Husted C, Chen C, Thiagarajan K, Johns JL, Rao SP, Alvira CM et al (2015) (2015) Activation of the nuclear factor-kB pathway during postnatal lung inflammation preserves alveolarization by suppressing 
macrophage inflammatory protein-2. Am J Physiol Lung Cell Mol Physiol 309:L593-L604. doi:10.1152/ajplung.00029.2015

53. McKenna S, Michaelis KA, Agboke F, Liu T, Han K, Yang G, Dennery PA, Wright CJ et al (2014) Sustained hyperoxia-induced NF-kB activation improves survival and preserves lung development in neonatal mice. Am J Phyiol Lung Cell Mol Physiol 306:L1078-L1089. doi:10.1152/ajplung.00001.2014

54. Ehrhardt H, Pritzke Z, Oak P, Kossert M, Biebach L, Förster K, Koschlig M, Alvira CM, Hilgendorff A. Absence of TNF-a enhances inflammatory response in the newborn lung undergoing mechanical ventilation. Am J Physiol Lung Cell Mol Physiol. In press. 2016. doi: 10.1152/ajplung.00367.2015.

55. Bird AD, McDougall AR, Seow B, Hooper SB, Cole TJ (2015) Glucocorticoid regulation of lung development: lessons learned from conditional GR knockout mice. Mol Endocrinol 29(2):158-171. doi:10.1210/me.2014-1362

56. Lukkarinen $\mathrm{H}$, Hogmalm A, Lappalainen U, Bry K et al (2009) Matrix metallopro-teinase-9 deficiency worsens lung injury in a model of bronchopulmonary dysplasia. Am J Respir Cell Mol Biol 41(1):59-68. doi:10.1165/rcmb.2008-01790C

57. Lukkarinen H, Hogmalm A, Lappalainen U, Bry K et al (2009) Matrix metalloproteinase-9 deficiency worsens lung injury in a model of bronchopulmonary dysplasia. Am J Rspir Crit Care Med 41(1):59-68. doi:10.1165/rcmb.2008-01790C

58. Gauldie J, Galt T, Bonniaud P, Robbins C, Kelly M, Warburton D et al (2003) Transfer of the active form of transforming growth factor-beta 1 gene to newborn rat lung induces changes consistent with bronchopulmonary dysplasia. Am J Pathol 163(6):2575-2584, http://dx.doi.org/10.1016/S00029440(10)63612-7

59. Bonniaud P, Kolb M, Galt T, Robertson J, Robbins C, Stampfli M, Lavery C, Margetts PJ, Roberts AB, Gauldie J et al (2004) Smad3 null mice develop airspace enlargement and are resistant to TGF-betamediated pulmonary fibrosis. J Immunol 173(3):2099-2108. doi:10.4049/jimmunol. 173.3.2099

60. Wang H, Jafri A, Martin RJ, Nnanabu J, Farver C, Prakash YS, MacFarlane PM et al (2014) Severity of neonatal hyperoxia determines structural and functional changes in developing mouse airway. Am J Physiol Lung Cell Mol Physiol 307(4):L295-L301. doi:10.1152/ajplung.00208.2013

61. Rieger-Fackeldey E, Park MS, Schanbacher BL, Joshi MS, Chicoine LG, Nelin LD, Bauer JA, Welty SE, Smith CV et al (2014) Lung development alterations in newborn mice after recovery from exposure to sublethal hyperoxia. Am 」 Pathol 184(4):1010-1016. doi:10.1016/j.jpath.2013.12.021

62. Morley CJ, Davis PG, Doyle LW, Brion LP, Hascoet JM, Carlin JB, Trial Investigators COIN et al (2008) Nasal CPAP or intubation at birth for very preterm infants. N Engl J Med 358(7):700-708. doi:10.1056/ NEJMoa072788

63. Finer NN, Carlo WA, Walsh MC, Rich W, Gantz MG, Laptook AR, Yoder BA, Faix RG, Das A, Poole WK, Donovan EF, Newman NS, Ambalavanan N, Frantz ID 3rd, Buchter S, Sánchez PJ, Kennedy KA, Laroia N, Poindexter BB, Cotten CM, Van Meurs KP, Duara S, Narendran V, Sood BG, O'Shea TM, Bell EF, Bhandari V, Watterberg KL, Higgins RD et al (2010) Early CPAP versus surfactant in extremely preterm infants. N Engl J Med 362(21):1970-1979. doi:10.1056/NEJMoa0911783

64. Stevens TP, Finer NN, Carlo WA, Szilagyi PG, Phelps DL, Walsh MC, Gantz MG, Laptook AR, Yoder BA, Faix RG, Newman JE, Das A, Do BT, Schibler K, Rich W, Newman NS, Ehrenkranz RA, Peralta-Carcelen M, Vohr BR, Wilson-Costello DE, Yolton K, Heyne RJ, Evans PW, Vaucher YE, Adams-Chapman I, McGowan EC, Bodnar A, Pappas A, Hintz SR, Acarregui MJ, Fuller J, Goldstein RF, Bauer CR, O'Shea TM, Myers GJ, Higgins RD et al (2014) Respiratory outcomes of the surfactant positive pressure and oximetry randomized trial (SUPPORT). J Pediatr 165(2):240-249. doi:10.1016/j.jpeds.2014.02.054

65. Zivanovic S, Peacock J, Alcazar-Paris M, Lo JW, Lunt A, Marlow N, Calvert S, Greenough A et al (2014) Late outcomes of a randomized trial of high-frequency oscillation in neonates. N Engl J Med 370(12):1121-1130. doi:10.1056/NEJMoa1309220

66. Thome UH, Genzel-Boroviczeny O, Bohnhorst B, Schmid M, Fuchs H, Rohde O, Avenarius S, Topf HG, Zimmermann A, Faas D, Timme K, Kleinlein B, Buxmann H, Schenk W, Segerer H, Teig N, Gebauer C, Hentschel R, Heckmann M, Schlösser R, Peters J, Rossi R, Rascher W, Böttger R, Seidenberg J, Hansen G, Zernickel M, Alzen G, Dreyhaupt J, Muche R, Hummler HD et al (2015) Permissive hypercapnia in extremely low birthweight infants (PHELBI): a randomised controlled multicentre trial. Lancet Respir Med 3(7):534-543. doi:10.1016/S2213-2600(15)00204-0
67. Manja V, Lakshminrusimha S, Cook DJ et al (2015) Oxygen saturation target range for extremely preterm infants: a systematic review and meta-analysis. JAMA Pediatr 169(4):332-340. doi:10.1001/jamapediatrics.2014.3307

68. Seger N, Soll R (2009) Animal derived surfactant extract for treatment of respiratory distress syndrome. Cochrane Database Syst Rev 15(2):CD007836. doi:10.1002/14651858.CD007836

69. Göpel W, Kribs A, Ziegler A, Laux R, Hoehn T, Wieg C, Siegel J, Avenarius S, von der Wense A, Vochem M, Groneck P, Weller U, Möller J, Härtel C, Haller S, Roth B, Herting E et al (2011) Avoidance of mechanical ventilation by surfactant treatment of spontaneously breathing preterm infants (AMV): an open-label, randomised, controlled trial. Lancet 378(9803):1627-1634. doi:10.1016/S0140-6736(11)60986-0

70. Kribs A, Roll C, Göpel W, Wieg C, Groneck P, Laux R, Teig N, Hoehn T, Böhm W, Welzing L, Vochem M, Hoppenz M, Bührer C, Mehler K, Stützer H, Franklin J, Stöhr A, Herting E, Roth B et al (2015) Nonintubated surfactant application vs Conventional Therapy in Extremely Preterm Infants: A Randomized Clinical Trial. JAMA Pediatr 169(8):723-730. doi:10.1001/ jamapediatrics.2015.0504

71. Göpel W, Kribs A, Härtel C, Avenarius S, Teig N, Groneck P, Olbertz D, Roll C, Vochem M, Weller U, von der Wense A, Wieg C, Wintgens J, Preuss M, Ziegler A, Roth B, Herting E, German Neonatal Network (GNN) et al (2015) Less invasive surfactant administration is associated with improved pulmonary outcomes in spontaneously breathing preterm infants. Acta Paediatr 104:241-246. doi:10.1111/apa.12883

72. Donohue PK, Gilmore MM, Cristofalo E, Wilson RF, Weiner JZ, Lau BD, Robinson KA, Allen MC et al (2011) Inhaled nitric oxide in preterm infants: a systematic review. Pediatrics 127(2):e414-e422. doi:10.1542/peds.2010-3428

\section{Submit your manuscript to a SpringerOpen ${ }^{\circ}$ journal and benefit from:}

- Convenient online submission

- Rigorous peer review

- Immediate publication on acceptance

- Open access: articles freely available online

- High visibility within the field

- Retaining the copyright to your article

Submit your next manuscript at $\gg$ springeropen.com 